NGTT Deel 54, Nommers 3 \& 4, September en Desember 2013

Tshaka, Rothney $\mathrm{S}^{1}$

University of South Africa

\title{
Confessional theology a belligerently public theology - How confessional theology relates to notions of Africanness and Reformedness
}

\begin{abstract}
Confessional theology, while insisting on the centrality of the Word of God in theological reflection, admits that the socio-economic, cultural and political context in which such reflection takes place is vital. In paying homage to the theological contribution of Dirkie Smit in South Africa, this article argues that this is the most opportune time to consider how marginal issues of Africa still are in theological reflection today. Taking the baton from Smit, it is argued that confessional theology, if it is to remain relevant, must deal with issues of Africanness in theological reflections today.
\end{abstract}

\section{INTRODUCTION}

First allow me to express my heartfelt appreciation for the invitation to contribute in this Festschrift in celebration of the 60th birthday of my Doktorvater, Dirkie Smit. I am certain that most of the students that happened to find themselves under his tutelage would agree that he is indeed a theologian par excellence. Allowing his students their own views is not strange to him. It was especially this attitude that had allowed me to disagree freely with him. To my mind, Smit also has what I would like to call "an intelligent sense of humour". Dry in appearance, his humour is both intelligent and very funny.

Dirkie Smit is an avid reader of Reformed theology, especially the theology of John Calvin. I vividly remember the numerous times when he likened me to one student of Calvin of whom the latter once noted, must be thinking secretly that the old Calvin had lost some of his marbles when advising him on some issues. I must admit, however, that Smit was correct with his observation regarding me, for I did from time to time think that this great theologian and son of the church must be losing some from time to time. Still, there remains no doubt in my mind that Smit will be remembered for his immense contribution to theology in this country and the world in general.

I wish to partake in the celebration of his theological contribution both into confessional theological studies and its relations to the realities from which such confessions emanate. I wish to make my contribution by looking at the following: first, this paper will probe the notion of "confessional theology", looking especially at how that great Protestant theologian of the twentieth century Karl Barth impacted on the theological reflection of Dirkie Smit. In this endeavour I shall call to mind the Belhar Confession as an epitome of his theological deliberations. It will be argued that, just as it can be claimed that the Barmen Theological

1 Prof. Rothney Tshaka is Chairperson of the Department of Philophy, Practical and Systematic Theology,

University of South Africa. 
NGTT: Oopbron - http://ngtt.journals.ac.za

Declaration gives a brief overview of the theology of Karl Barth, so can it be claimed that the Belhar Confession presents us with an overview of the theology of Smit. Therefore, if one wishes to understand not only the theology of Smit, but more concretely its relationship to concrete realities, the Belhar Confession remains an important yardstick for measuring that.

Some similarities can be observed between Barth and Smit and this is merely because of the extent to which Barth had influenced Smit. I am, of course, aware that for Smit such a comparison might be problematic, yet I nonetheless wish to reflect on it some, especially as I refer to current issues. Smit has become known as a Reformed theologian who places a premium on Reformed spirituality. For some his emphasis on Reformed spirituality at first created the impression that all else is subservient to it. For students like me, who associated with the black consciousness movement, it was very easy to look at such theological talk with much scepticism. However, with this perception in mind, this paper will show how his staunch "Reformedness" in fact rendered Smit a formidable public theologian. Of course it cannot be expected of him to address all challenges that faced and continues to face theological discourse, yet the biases with which one enters these debates has to be acknowledged.

This paper will argue that Smit managed to become a public theologian of note primarily because he was able to articulate, for himself first, the essence of Reformed theology and its innate inclination to be geared towards the public. Having established that, I shall then return to what I believe to be very important conversations that are long overdue and remain marginal in all major Reformed theological discourse in South Africa, namely those on "Africanness" and its relationship to "Reformedness".

\section{The Confessional Theology of Dirkie Smit}

One cannot really appreciate the question regarding Smit's confessional theology without admitting from the outset that this is intimately linked to his Reformed faith. In fact, when one reflects on his theological engagements during and after apartheid, one quickly realises how, also in his best criticism of the heresy of apartheid, he remained convinced of the many noble intentions of the Reformed faith. Put differently, Reformed faith was never to be totally overhauled simply because of the misapplications by some in order to sanction an establishment that had its own motives, an establishment that, at best, remained contrary to the faith. Obviously Reformed faith took the issue of spiritually very seriously. It is, therefore, not by chance that it takes centre stage in Smit's theological reflections. However, whether his emphasis on Reformed spirituality was done to the satisfaction of many who were not part of the main stream of the faith remains something to be considered.

One could perhaps argue that one of the reasons why Smit, and others like him in the Reformed tradition, chose to challenge the legitimacy of the apartheid ideology was their conviction that it was a struggle for the heart of the Reformed faith. Smit refers to five central debates involved in this struggle - these debates also touch on the characteristics of his confessional theology. These are

the conflicts about the Reformed understanding and use of the Word of God, the Reformed understanding of the church, the Reformed understanding of the truth of the gospel, the Reformed understanding of the concrete, visible and practical embodiment of this gospel, and the Reformed understanding of God's caring (Smit 2007b:31-32). 
NGTT Deel 54, Nommers 3 \& 4, September en Desember 2013

I shall not reiterate Smit's extensive treatment of these debates here but simply wish to point out how his conviction that the legitimacy of apartheid was beyond defence enabled him to return to central Reformed teachings and values in order to challenge the supposed theological legitimacy of apartheid. I refer to them in summary to illustrate my point:

The first struggle revolved around the issue of the struggle regarding the Bible (2007b:31). Smit contends, and rightly so, that the reading of the Bible during apartheid was often a rather controversial matter. This was simply so because it (the Bible) was used to give theological and biblical legitimacy to apartheid. It is not by chance that the dominant biblical hermeneutics increasingly became suspect for those within the antiapartheid camp - also, and especially, within the Reformed tradition. Black liberation theology, which be came an alternative biblical hermeneutics, increasingly met with disapproval from those in dominant biblical hermeneutics.

Closely linked to this struggle was a struggle for the church (2007:32). Given the relationship of the Bible to the church, this was to be expected. If the Bible and, therefore, theology is to be a phenomenon that is more at home within the ambit of the church, it follows naturally that significant questions relating to the latter's life and mission must come to light. The different camps within the Reformed tradition (that is, those supporting and challenging apartheid) had to battle out how the church had to visibly affirm a position supporting the legitimacy of apartheid or how to visibly challenge such legitimacy. When it comes to this one can clearly see, as Smit observes, how there remained resources within the very Reformed tradition for supporting apartheid and yet, at the same time, there were also resources that vigorously challenged it. Among these resources, Smit remains at pains to refer to the tradition of Calvin as well as to the confessional documents of this tradition to discern will of God and "to stand (unapologetically) where God stands".

This leads one to the third struggle, namely the struggle for the truth (2007b:33). If it is true that there have always been different views within the Reformed tradition, then we must ponder the question of what then is the truth. Since we stand in a particular tradition, we need to concede to the fact that our challenges might be unique to our situation, yet we also stand on the shoulders of those who went before us. According to Smit, we must, therefore, ask whether the likes of Calvin would have dismissed apartheid as simply adiaphora and, therefore, as something that does not really threaten the central message of the Bible. Many would undoubtedly have loved to look at apartheid as exactly that, a neutral matter that in essence does not challenge the gospel. It was precisely because of this that the former Dutch Reformed Mission Church (DRMC) challenged apartheid as something that made a mockery of the Christian message.

The DRMC needed to confess simply because they felt they were with their backs to the wall and could do nothing else. Admitting that there are different ways one might read and interpret Scripture, a status confessionis was declared, not to have the better and the right word, but as a commentary on the dominant hermeneutics until such time when all will have realised the error of their ways. Of course, the idea of confession is not unique to our situation. In fact, it goes back to the time of the Reformation itself.

A fourth struggle that Smit refers to is the struggle for the embodiment of that truth (2007:34). Smit argues that one of the most challenging aspects of the struggle for truth was not only to confess the truth, but to embody it. He realises that it is one thing to 
NGTT: Oopbron - http://ngtt.journals.ac.za

confess, yet it is a totally different matter to embody that which one confesses. Embodiment suggests that one lives out those confessed values - it is, therefore, not by chance that the church order of URCSA had to be overhauled so that it gave concrete testimony to what is confessed in the Belhar Confession. The final struggle is one which centres on Calvin's legacy regarding God's caring, and liberating justice (2007:37). Contrary to the impression among many Reformed Christians, Smit points out in a very real sense that confessions of faith are in fact very much related to the contexts in which they originate. That the Belhar Confession explicitly refers to notions of justice, unity, and reconciliation is not unique to it. In fact, Smit argues, this is directly influenced by Calvin's socioeconomic thought.

I have argued elsewhere that while Barth credits Luther for having influenced him immensely, he nonetheless places Calvin at the top of his list of those who had brought about in him a new way looking at Reformed confessional writings (Tshaka 2010b:32ff.). For these reasons I assert that Smit is rather Barthian in his approach to Reformed confessions. There is, for Smit, just as it was for Barth, an organic link between confessing and embodying what has been confessed. A confession without such embodiment, therefore, remains unacceptable both to Barth as well as to Smit as we shall see.

\section{Confessing and embodying the Belhar Confession}

The above leads to the question: How the Belhar Confession should be understood today? Another factor worth considering is the ecclesial authority that governs this veryconfession. How should the Confession be interpreted in light of today's changed and changing context? In addition to this, we are challenged by our reflection on Belhar to look back in order to more clearly engage the present circumstances. It is thus not by chance that the Belhar Confession constantly reminds one of the situation in which it originated, yet its past is to be brought into critical dialogue with the present. The Belhar Confession can only retain its relevance if it is allowed to be a blueprint for new challenges.

A few things ought to be taken into consideration in pondering the essence of Belhar for present day South Africa. At first glance one notices a distinction between confessing and embodying the confession. While the former seems to be widespread within the Reformed tradition, the latter warrants brief explanation. to embody something suggests that something is incorporated into something else. With this one can conclude that a call is being made today on those confessing Belhar to incorporate it into their very being. There are, of course, a number of ways in which this call can be heeded; we shall not deal at length with that here, except to point toward the essence of particularity in dealing with new challenges.

The essence of particularity must be observed as we strive towards making this confession a practical reality for us today. For many in URCSA, to embody Belhar means that URCSA is the Belhar Confession (cf. Smit 2000). It is, how ever, not enough to merely say that the URCSA is the Belhar Confession. Such a statement needs to be substantiated in order to gain clarity on the circumstances that sanction such a claim. The Belhar Confession is a bold statement that can be embodied only when one explains why it is a relevant and a necessary commentary on alternative, entrenched half-truths.

Talk on the embodiment of the Belhar Confession can also be understood negatively. To speak about the truth that is encapsulated in this confession with out assessing the new situation in which this is currently being uttered can also tempt one to absolutes Belhar as 
NGTT Deel 54, Nommers $3 \& 4$, September en Desember 2013

the ultimate truth. Barth remained very cautious of such attempts. His caution was informed by the temporal nature of any human statements about God. It was not by chance that he stated in no uncertain terms, at the meeting of the World Alliance of Reformed Churches in Cardiff in 1925, that a Christian confession must take its particular context seriously (cf. Barth 1962:112). I am of the view that with this Barth also wanted to point to the "humanness" of a very confession. It is possible for one to embody something to the extent that one is unable to transcend that which one has incorporated into one's being. This must be guarded against by all means.

It is only by considering some characteristics of a confession that we will be able to guard against the temptation of absolutising that which we had embodied. It is imperative to pay heed of this because, as Naudé indicates, the socio economic and political developments that precede and "inform" a confession are mostly not neutral, and - due to their theological interpretation by the Confession are themselves at stake in the act of confession (Naudé 2003:157).

Although the story and historicity of Belhar is well documented, both locally and internationally, within Reformed circles knowledge about this Confession within the ranks of URCSA leaves much to be desired. Like so many confessions that preceded it, Belhar was called into being by the socioeconomic and political circumstances and theological consideration that divided people in terms of race and colour. The Belhar Confession boldly takes its cue from the Barmen Declaration which questioned the Nazi state's involvement in determining the membership to the church of Christ.

As the chief exponent of the Barmen Declaration, Barth began to wrestle with Reformed theology or confessional theology at a rather late stage in his theological metamorphosis. It was only when he cut ties with liberal theology and was compelled to read Reformed theology more closely in preparation for his lectures at a predominantly Lutheran faculty at Göttingen in the early 1920s that he developed a deeper appreciation of the Reformed tradition. Shortly before this incident, Barth came to understand the mystery that governs the Word of God. With his endeavours to come to terms with the paradox of having to speak about God because we are charged by Him to do so, and yet being con fronted with an impossibility of executing this command simply because we are human and therefore fallible, he came to the conclusion that due to the church's existence within the world, the church has to say something.

McCormack was thus correct when he asserted that, to the issues of ecclesial authority, the nature of a church confession, and the obedience that is proper to such a confession, no Reformed theologian in this century has afforded more attention than Barth (McCormack 2003:53). Barth's involvement with confessional writings, which let him to conclude that they (confessions) occupied a pivotal role within the Reformed tradition, had allowed him the opportunity to understand the complexity that surrounds confessions. His maturity and authority concerning this subject was revealed when the World Alliance of Reformed Churches (already mentioned above) requested of him to comment on the desirability and possibility of a universal Reformed creed (Barth 1962:112ff.). More importantly, most of Barth's views that informed his approach to confessional theology as well as his views concerning the problem of ecclesial authority, which was an obstacle during the 1920s, were tested during this period and was to remain with him until the end of his life.

In response to the critique against his dialectic theology by a Catholic friend (Erik Peterson), 
NGTT: Oopbron - http://ngtt.journals.ac.za

Barth maintained that certain factors constitute the concrete authority of the church: (1) the decision of the church on the canon and the text of the Bible; (2) creeds - or the decisions of the church on fundamental statements of faith that have been more or less unanimously acknowledged; (3) "fathers" or "doctors of the Church" who have been acknowledged by the church(es) as faithful expositors of those authoritative creedal statements, and; (4) the "command of the hour" (the "definiteness of the moment") in which theology finds itself, which lays upon it an obligation to speak to the real needs of the present (Barth 1962:291; McCormack 2003:56). These four factors taken together constitute ecclesial authority.

The context in which the Reformed church finds itself today differs vastly from the context of that of the sixteenth century were membership to a church was bound to a common confession (McCormack 2003:46). Having pointed this out, it cannot be denied that the very concrete authority which informs the character of the church is still necessary and relevant in this context. The challenge is seeing how it speaks to current issues today.

For Barth, a Reformed confession is spontaneously and publicly formulated. It is not something that fell from heaven, but which is confessed by those who subscribe to it and, therefore, it is a product of and for the community. Certainly, it may be concluded that, in line with Reformed tradition, Barth understood a confession to be merely a comment on the Word of God and not the Word of God as such. It is also clear that Barth realised that a confession should be treated as being open to discussion and improvement. This is important to note since Reformed confessions differ from Lutheran confessions in that the former do not expect all Reformed communities to subscribe to them (Smit, publication forthcoming). Lutheranism ascribes decisive importance to the unity and the uniform interpretation of its confessions (Barth 2002:2). Reformed confessions completely lack the characteristic of ecumenical publicity. It is this lack of uniform interpretation of a particular confession that has left Reformed believers open to the charge of confessionalism.

It is imperative that, to start with, one reflects on the essence of confessional theology especially in light of the many challenges that face South Africa today. But what are these many challenges? They are varied and are prioritised differently depending on the context of those that do so. There are indeed many "South Africa's" in South Africa. What would, therefore, be construed as "important" in one section of this country might not be viewed as such in another. However, all would agree that in this country a scandalous gap exists between those who live in opulence as well as those who live in abject poverty. This difference did not develop by chance as many would like to believe, but was a calculated move to ensure that ultimately those on the underside of history will resign themselves to their subjugation in society (cf. Tshaka and Makofane 2010:532-546).By reflecting on confessional theology and acknowledging that confessional theology remains true to the particular contexts in which it originated, we in this way remain true to our Reformed heritage. This requires from us to also acknowledge confessional theology's humanness and, therefore, its limitations and it belligerently admits that it is merely a comment on the Word of God as are all other confessions. However, it is a specific kind of commentary on the Word; it is a bold "NO!" that remains aware that there may come a time when the emphases found in it might be placed differently. In essence, it is a commentary that is made by fallible men and women who are called to speak about God and yet are unable to do so because of their own fallibility.

In Barth's explanation of the impossibility of a universal Reformed confession he maintains that this is because there are particular instances that give rise and structure to confessions. It is in 
NGTT Deel 54, Nommers 3 \& 4, September en Desember 2013

light of these particular instances that Reformed churches confess "until further notice" (Barth 1962:119). Smit asserts that the latter phrase serves the purpose of defining the character of a confession authoritatively to its outsiders, while at the same time giving direction to its own doctrine and life (Smit, forthcoming). One can also appreciate this insight when one recognises that the church exists within the world and that it has to frequently familiarise itself with what is going on in the world.

This brings us to another very important subject that, in my opinion, has not enjoyed the necessary attention in the past, yet it remains a cardinal problem if we are really to understand the problems facing (mostly black) communities in South Africa. While it is necessary and proper that we must celebrate the immense contribution by the Reformed faith through many of its faithful exponents, such as Barth and Smit, it is also necessary that we deal with what was not said clearly or forcefully enough. Substantial research had been conducted on the hermeneutics of apartheid employed by those who justified the subhuman position of those who were not considered white. However, while one finds studies on politics and, to a lesser extent, on economics and how this is related to the Reformed faith in South Africa, virtually nothing was done to advocate Africanness and its relationship to being reformed. It is this absence that this paper wants to probe below.

\section{Africanness and its RELATION to Reformedness}

It is precisely because confessional theology is public theology that it must take seriously its particular context. The particular context of confessional theology in South Africa is its African context and reality. ${ }^{2}$ While one must never lose sight of the fact that confessional theology was immensely influenced by the fathers of the Reformed tradition, it nevertheless must deal with its particular African realities. What is this African context that has to be taken seriously if Reformed faith is to retain its significance and relevance on this continent? Africa essentially is a continent characterised by different world views and cultures. At the same time it is a continent plagued by conflict and war, disease and famine. It has a well-documented history of colonialism and was pillaged and maimed by Western colonial powers for their own benefit. In short, Africa is a context full of complexities.

I contend that Reformed faith and, therefore, confessional theology, while in later years attempting to challenge the rogue biblical hermeneutics propagated by apartheid theology, did virtually nothing to establish an intentional platform for a much needed conversation on Africanness and Reformedness. It cannot be denied that the deliberate attempts at

\footnotetext{
2 In the summer of 1968 Barth received a letter from Singapore by someone unknown to him. It was from Kosuke Koyama who had translated Barth's Christian Dogmatics into Japanese. Koyama was a Japanese missionary and had been involved for some years with the Theological Seminary of Thailand, becoming Dean of the South East Asia Graduate School of Theology. He later took over the position of editor of the South East Asia Journal of Theology. Koyama wrote to Barth with a request that he write something about his (Barth's) theology for this journal. At the time Barth was ailing and permitted his assistant Eberhard Busch to see to this request. Busch compiled some of the issues that Barth was thinking about at the time and Barth endorsed them. However, there are a number of important issues that Barth thought he had to communicate to these Christians. In the letter Barth made it clear that "boring theology" was unacceptable and that it had was time for these Christians to understand that it was now the time for them to speak and for him to listen. Barth continued to make it clear that theology had to be conducted with a degree of humour and, more importantly, that they had to understand that the God who they were talking about was also his God. They should not repeat what he said in a different context, but should appropriate that which will be relevant in their context. For the details of the letter cf. Barth 1984:555.
} 
NGTT: Oopbron - http://ngtt.journals.ac.za

establishing this faith in South Africa without promoting integration between this new faith and African culture was informed by agendas that were convinced that Africa had nothing to contribute to this debate. In fact, it was thought that it would be more worthwhile to lose one's (African) identity in one's attempt to be welcomed into this faith.

It is sometimes asked: What is meant when the Africanisation of the Reformed church in Africa is called for? While this might be a legitimate question, something sinister often hides behind it. Sometimes it is ignorance but mostly it is some ill begotten notion of Africa and its people. Be that as it may, one should admit with Kwame Nkrumah that the meeting between African ways of life and those of the rest of the world had placed Africa and its people on a road of no return from the rock whence they were hewn. Nkrumah quite poignantly writes that

...the defeat of colonialism and even neo-colonialism will not result in the automatic disappearance of the imported patterns of thought and social organization. For those patterns have taken root, and are in varying degree socio logical features of our contemporary society. Nor will a simple return to the communalistic society of ancient Africa offer a solution either. To advocate a return, as it were, to the rock from which we were hewn is a charming thought but we are faced with contemporary problems, which have arisen from political subjugation, economic exploitation etc. (Nkrumah 1967).

I have argued elsewhere that this very important acknowledgement is not to be confused with sentiments held by some that Africa must forever remain grateful to the West for having brought the Christian faith to it - even though they exploited the continent in exchange (Tshaka 2009:116). In fact, Nkrumah was very serious about the need for an African consciousness. He had the following to say about the African colonial student:

A colonial student does not by origin belong to the intellectual history in which the university philosophers are such impressive landmarks. The colonial student can be so seduced by these attempts to give philosophical account of the universe, that he [sic] surrenders his whole personality to them. When he does this, he loses sight of the fundamental societal fact that he is a colonial subject (Nkrumah 1966:2).

One can, therefore, understand why it is always expected that when the concepts "Africa" and "African" is mentioned, more always needs to be said. Yet it is not recognised by the very people who "ask that more be said so that the notions become intelligible" that this happens precisely because there are some notions that are deemed normative while others are not. $A$ case in point is the usage of "Africanness" and "Reformedness" in the same vein. In the debate on the latter, Reformedness is the unexamined norm to which all else must rise to. It is for this reason that a degree of uneasiness becomes apparent when a space for dialogue on and between these phenomena, which remains a tangible reality at least to the African Christian, are insisted upon. In a similar observation, Maluleke (2010) correctly asserts that

\footnotetext{
...the idea that Christianity could be Africanised has been viewed as suspect - either because it is assumed that Christianity is universal or that Africanization can only mean a lowering of universal "Christian standards" in order to fit in with some local "African standards".
}

Having noted these challenges, at the end of the day it remains the responsibility of the black African Reformed Christian to see to it that Africanness in theological deliberations does not only remain an unimportant appendix. The attempt to take it seriously needs to find 
NGTT Deel 54, Nommers $3 \& 4$, September en Desember 2013

expression particularly also in curricula (Tshaka 2009). African and Reformed theology need to acknowledge a particular history that in essence contributed towards a flight from the black self. The repercussions of this have been devastating as is evidenced by the Afro-phobic attacks on Africans north of the Limpopo (Tshaka 2010a).

\section{Towards creating a space for debating Africanness and Reformedness}

Statistics indicate that Christianity is increasingly gravitating towards the global South (Bedaiko 2008:107). Reformed theology in South Africa had become notorious for insisting on academic standards. In essence, as in so many main line church traditions, Reformed theology had indiscriminately imposed its methodologies without looking for ways to learn from the African situation. We have already alluded in passing to this attitude in this paper. However, the fact that there is much talk about Christianity changing its face does leave some with the impression that perhaps there is much that can be learned from the African and his or her context. Academic theology, which in South Africa has become a synonym for Reformed theology, has always been judgmental toward those theologies that were not enmeshed in rigorous method. In this process it had lost a significant opportunity of bringing about serious debate between the academy and the very community that scholarly activities were supposed to serve.

Statistics indicate that Christianity is increasingly gravitating towards the global South (Bedaiko 2008:107). Reformed theology in South Africa had become notorious for insisting on academic standards. In essence, as in so many mainline church-traditions, Reformed theology had indiscriminately imposed its methodologies without looking for ways to learn from the African situation. We have already alluded in passing to this attitude in this paper. However, the fact that there is much talk about Christianity changing its face does leave some with the impression that perhaps there is much that can be learned from the African and his or her context. Academic theology, which in South Africa has become a synonym for Reformed theology, has always been judgmental toward those theologies that were not enmeshed in rigorous method. In this process it had lost a significant opportunity of bringing about serious debate between the academy and the very community that scholarly activities were supposed to serve.

\section{BIBLIOGRAPHY}

Barth, K. 1962. Theology and Church. London: SCM.

Barth, K. 1984. Offene Briefe: 1945-1968. Zürich: Theologischer Verlag.

Barth, K. 2002. The Theology of the Reformed Confessions. Louisville, KY: Westminster/ John Knox.

Bediako, K. 2008. Whose Religion is Christianity? Reflections on Opportunities and challenges in Christian

Theological Scholarship: The African Dimension. In Walls, A. and Ross, C. (Eds.),

Mission in the 21st Century: Exploring the Five Marks of Global Mission. Maryknoll, NY: Orbis 107-117.

Maluleke, T. S. 2010. Of Africanised Bees and Africanised Churches: Ten Theses on African Christianity. Missionalia 38 (November), 369-379.

McCormack, B. 2003. The End of Reformed Theology? The Voice of Karl Barth in the Doctrinal Chaos of the Present. In Alston, W. Jr. and Welker, M. (eds.), Reformed Theology: Identity and Ecumenicity. Grand Rapids, Ml: Eerdmans, 46-64.

Nkrumah, K. 1966. Consciencism: Philosophy and Ideology for Decolonization and Development with Particular Reference to the African Revolution. London: Heinemann. Nkrumah, K. 1967. African socialism revisited. Online at http://www.marxists.org/ subject/africa/ nkrumah/1967/africansocialismrevisited.htm. [2011, March, 11]. Naudé, P. J. 2003. The Theological Coherence Between the Belhar Confession and Some Antecedent 
NGTT: Oopbron - http://ngtt.journals.ac.za

Church Witnesses in the Period 1948-1982. Verbum et Ecclesia 24(1), 156179. Smit, D. J. 2000 Versoening - en Belhar? (Reconcilliation - and Belhar?) Gereformeerde Theologisch Tijdschrift (4), 159173.

Smit, D. J. 2007a. Essays in Public Theology: Collected Essays 1. Conradie, E. M. (ed.) Stellenbosch: Sun Press.

Smit, D. J. 2007b. Reformed Faith, Justice and the Struggle against Apartheid. In Essays in Public Theology: Collected Essays 1, 31-32.

Smit, D. J. Publication forthcoming. Reformed Confessions and Ecumenical Reception - On the Confession of Belhar and Reconciliation.

Tshaka, R. S. 2009. Academic Theology as the Yardstick of Being Reformed in South Africa

Today: An Appreciative Critique of Calvin on the Occasion of His 500th Birthday. Studia Historiae Ecclesiasticae XXXV (December), 1-16.

Tshaka, R. S. and Makofane, K. M. 2010. The Continued Relevance of Black Liberation Theology for Democratic South Africa Today. Scriptura (105), 532-546.

Tshaka, R. S. 2010a. Do Our Theological Methodologies Help Us to Deal with Situations of Violence in Black Communities, Specifically Afrophobia. JTSA 138.

Tshaka, R. S. 2010b. Confessional Theology? A Critical Analysis of the Theology of Karl Barth and its Significance for the Belhar Confession. New Castle: Cambridge Scholars.

\section{TREFWOORDE}

Afrikaanheid

Konfessionale Teologie

Gereformeerde Teologie

Apartheid

Menswees

\section{KEY WORDS}

Africanness

Confessional Theology

Reformed Theology

Apartheid

Humanity

Contact Details/Kontakbesonderhede

Prof RS Tshaka

Chair

Department of Philosophy, Practical and Systematic Theology

Samuael Pauw Bui;Iding room 4-45

Preller Street, Muckleneuk

0124294053

Unisa

PO Box 392

0003 PRETORIA

E-mail:tshakars@unisa.ac.za 